\title{
Extraction of Nitric Acid, Americium(III), Curium(III) and Lanthanides(III) into DMDOHEMA Dissolved in Kerosene
}

\author{
Andreas Geist, ${ }^{\mathrm{a}}$ Laurence Berthon, ${ }^{\mathrm{b}}$ Marie-Christine Charbonnel, ${ }^{\mathrm{b}}$ Udo Müllich ${ }^{\mathrm{a}}$ \\ ${ }^{a}$ Karlsruhe Institute of Technology (KIT), Institute for Nuclear Waste Disposal (INE) \\ P. O. Box 3640, 76021 Karlsruhe, Germany \\ ${ }^{\mathrm{b}}$ CEA, DES, ISEC, DMRC, Univ. Montpellier, Marcoule, France
}

\begin{abstract}
Liquid-liquid distribution data were determined for the extraction of nitric acid, Am(III), $\mathrm{Cm}$ (III) and lanthanides(III) from $0.1-7 \mathrm{~mol} / \mathrm{L}$ nitric acid into $0.5-1 \mathrm{~mol} / \mathrm{L} N, N$ '-dimethyl$N, N$ '-dioctyl-2-[2-(hexyloxy)ethyl]-malonamide (DMDOHEMA) dissolved in kerosene. Nitric acid extraction was accurately modelled accounting for the adducts, $\left(\mathrm{HNO}_{3}\right) \mathrm{L}_{2}$, $\left(\mathrm{HNO}_{3}\right) \mathrm{L}$ and $\left(\mathrm{HNO}_{3}\right)_{2} \mathrm{~L}$. To model Am(III) extraction the following complexes were taken into account, $\mathrm{Am}\left(\mathrm{NO}_{3}\right)_{3} \mathrm{~L}_{4}, \mathrm{Am}\left(\mathrm{NO}_{3}\right)_{3}\left(\mathrm{HNO}_{3}\right) \mathrm{L}_{3}$ and a third complex: $\mathrm{Am}\left(\mathrm{NO}_{3}\right)_{3}\left(\mathrm{HNO}_{3}\right)_{2} \mathbf{L}_{3}$ (considering spectroscopic results) or $\mathrm{Am}\left(\mathrm{NO}_{3}\right)_{3}\left(\mathrm{HNO}_{3}\right)_{2} \mathbf{L}_{2}$ (considering slope analysis results). Separation factors for $\mathrm{Am}(\mathrm{III})$ over $\mathrm{Cm}$ (III) and the lighter lanthanides(III) are practically independent of nitric acid concentration. Am(III)/Ln(III) separation factors decrease with increasing nitric acid concentration for the heavier lanthanides(III).
\end{abstract}

\section{Keywords}

DMDOHEMA, nitric acid, americium(III), curium(III), lanthanides(III), extraction, equilibrium model, DIAMEX, GANEX

\section{Introduction}

Alkylated malonamides ${ }^{1-7}$ are used as extracting agents to co-extract tri-, tetra- and hexavalent actinides, An(III), An(IV), An(VI) and lanthanides, Ln(III), from highly acidic (3-5 mol/L $\mathrm{HNO}_{3}$ ) PUREX raffinate solutions, separating them from other fission products and corrosion products. This application is relevant in the context of advanced nuclear fuel cycles, and typically coupled to a subsequent separation of actinides from lanthanides. ${ }^{8-9}$ Recently, malonamides have been proposed as extracting agents for $\mathrm{Pd}(\mathrm{II}) .{ }^{10}$ 
Alkylated malonamides consist only of $\mathrm{C}, \mathrm{H}, \mathrm{O}$ and $\mathrm{N}$ atoms, making them combustible to gaseous products. This property is advantageous with respect to secondary waste management; ${ }^{11}$ no solid waste is generated from degradation products of the malonamides.

$N, N$ '-dimethyl- $N, N$ '-dioctyl-2-[2-(hexyloxy)ethyl]-malonamide (DMDOHEMA, Figure 1) ${ }^{12-}$ ${ }^{13}$ was selected the reference extracting agent for several actinide extraction processes under development at the French commissariat à l'énergie atomique et aux énergies alternatives (CEA) and other European laboratories. Initially, DMDOHEMA was used in the development and demonstration of DIAMEX (DIAMide EXtraction) processes ${ }^{14-18}$ to co-extract An(III) and Ln(III) from PUREX raffinate solutions. Later, DMDOHEMA was used in the development and demonstration of several processes combining An(III) and Ln(III) coextraction with selective $\mathrm{An}(\mathrm{III})^{19}$ or $\mathrm{Am}(\mathrm{III})^{20}$ stripping from the loaded organic phase. Finally, DMDOHEMA was also implemented in various GANEX (grouped actinides extraction) flow-sheets to co-separate $\mathrm{Np}(\mathrm{VI}), \mathrm{Pu}(\mathrm{IV}), \mathrm{Am}(\mathrm{III})$ and $\mathrm{Cm}(\mathrm{III}) .^{21-28}$

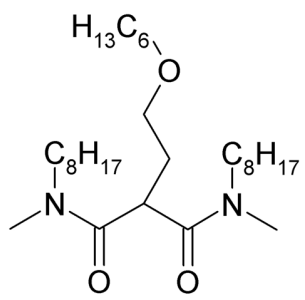

Figure 1. $N, N$ '-dimethyl- $N, N$ '-dioctyl-2-[2-(hexyloxy)ethyl]-malonamide (DMDOHEMA).

Several studies on the extraction of nitric acid and metal nitrates into alkylated malonamides (other than DMDOHEMA) and similar extracting agents have been published. The extraction of nitric acid is generally described by the formation of adducts such as $\mathrm{HNO}_{3} \mathrm{~L}_{2}$ and $\left(\mathrm{HNO}_{3}\right)_{x} \mathrm{~L}$ (with $\left.x=1-3\right) .{ }^{1}{ }^{29-32}$ Actinide(III) and lanthanide(III) nitrates are extracted from neutral nitrate solutions as $\mathrm{M}\left(\mathrm{NO}_{3}\right)_{3} \mathrm{~L}_{x}$ (with $\left.x=2-4\right){ }^{2}$, $33-36$ Some authors suggest the formation of several additional complexes, $\mathrm{M}\left(\mathrm{NO}_{3}\right)_{3}\left(\mathrm{HNO}_{3}\right)_{x} \mathrm{~L}_{y}$ (with $x=1-2$ and $y=2-4$ ) when extracting from nitric acid. ${ }^{2,32,37-38}$

Few studies report equilibrium distribution data for the extraction of nitric acid, actinides(III) and lanthanides(III) into DMDOHEMA dissolved in kerosene. ${ }^{13,34,39}$ Conclusions regarding the composition of the extracted metal ion complexes are contradictory:

A simple slope analysis, plotting $\lg \mathrm{D}_{\mathrm{M}(\mathrm{III})}$ vs. $\lg [\mathrm{L}]_{\mathrm{ini}}$ and $\lg \left[\mathrm{HNO}_{3}\right]_{\text {eq }}$, respectively, indicated the formation of $\mathrm{M}\left(\mathrm{NO}_{3}\right)_{3} \mathrm{~L}_{2}$ complexes upon extraction of $\mathrm{Am}(\mathrm{III}), \mathrm{Eu}(\mathrm{III})$ and $\mathrm{Nd}$ (III) from approximately $3 \mathrm{~mol} / \mathrm{L}$ nitric acid. ${ }^{39}$ The same study however concluded from a loading experiment using $\mathrm{Ce}(\mathrm{III})$ the formation of a $\mathrm{Ce}\left(\mathrm{NO}_{3}\right)_{3} \mathrm{~L}_{3}$ complex, for similar nitric 
acid concentration. Then again, complexes prepared by extracting $A m($ III) and $\mathrm{Ln}(\mathrm{III})(\mathrm{Nd}$, $\mathrm{Eu}, \mathrm{Yb})$ from $3 \mathrm{~mol} / \mathrm{L}$ nitric acid were identified by EXAFS as $\left[\mathrm{M}\left(\mathrm{NO}_{3}\right)_{3} \mathrm{~L}_{2}\right]$ or $\left[\mathrm{M}\left(\mathrm{NO}_{3}\right)_{3}\left(\mathrm{H}_{2} \mathrm{O}\right) \mathrm{L}_{2}\right]$ species. ${ }^{40}$ EXAFS and TRLFS analysis of DMDOHEMA organic phases loaded with $\mathrm{Eu}(\mathrm{III})$ showed speciation to depend on the acidity of the media: Extraction from acidic media resulted in the formation of $\left[\mathrm{Eu}\left(\kappa^{1}-\mathrm{NO}_{3}\right)_{3}\left(\mathrm{H}_{2} \mathrm{O}\right)_{1-2} \mathrm{~L}_{2}\right]$ while extraction from nonacidic media resulted in the formation of $\left[\mathrm{Eu}\left(\kappa^{2}-\mathrm{NO}_{3}\right)_{2}\left(\mathrm{H}_{2} \mathrm{O}\right)_{0-1} \mathrm{~L}_{2}\right]^{+}$, with additional outersphere DMDOHEMA molecules and an outer-sphere nitrate anion for charge compensation. ${ }^{41}$ Increasing the metal cation concentration in the organic phase was shown to promote changes in the speciation. ${ }^{42}$ The formation of $\left[\mathrm{CmL}_{4}\left(\mathrm{H}_{2} \mathrm{O}\right)\right]^{3+}$ and $\left[\mathrm{CmL}_{3}\left(\mathrm{NO}_{3}\right)\left(\mathrm{H}_{2} \mathrm{O}\right)_{2}\right]^{2+}$ complexes was identified by TRLFS at low and elevated nitric acid concentrations, respectively. ${ }^{43}$ The presence of one water molecule in the $\left[\mathrm{CmL}_{4}\left(\mathrm{H}_{2} \mathrm{O}\right)\right]^{3+}$ complex is in agreement with findings from an analogous Eu(III) complex. ${ }^{44}$

It needs to be considered that in alkane diluents DMDOHEMA forms polydisperse aggregates consisting of four to ten molecules, depending on the experimental conditions. ${ }^{41-42,}{ }^{45-51}$ The extraction of solutes (lanthanide nitrates or nitric acid) in macro concentrations promotes aggregation. All these data (molecular characterization and structure of the aggregates) show that organic solutions of malonamides are complex. A full description of the speciation requires a multiscale approach, combining experimental tools to characterize the molecular and supramolecular speciation with theoretical tools (such as molecular dynamics simulation). The identification of all equilibria involved and the associated constants is difficult and not mandatory to represent the equilibrium state. In this paper, we have chosen to describe the macroscopic behaviour (i.e., distribution of metal nitrates and nitric acid) using a simplified model, accounting for the major solute-ligand complexes or adducts.

The present paper reports distribution data for the extraction of nitric acid, Am(III), Cm(III) and $\mathrm{Ln}(\mathrm{III})$ from nitric acid $(0.1-7 \mathrm{~mol} / \mathrm{L})$ into DMDOHEMA $(0.5-1 \mathrm{~mol} / \mathrm{L})$ in TPH ("hydrogenated tetrapropene", a kerosene diluent). New data were collected for a couple of reasons: nitric acid distribution data are not available; the few Am(III) distribution data reported in references ${ }^{13}, 34$ and in reference ${ }^{39}$ are not in good agreement; no Ln(III) distribution except a few values for $\mathrm{Nd}(\mathrm{III})$ and $\mathrm{Eu}(\mathrm{III})$ are available. An equilibrium model for calculating nitric acid and metal nitrates distributions is presented, based on slope analysis and results from spectroscopy. ${ }^{43}$ The proposed model addresses flow-sheet calculations. It was kept rather simple, e. g. by neglecting non-ideality and aggregation ${ }^{41-42,45-51}$ in the organic phase. Nevertheless, it allows calculating distribution ratios with reasonable accuracy, over a wide range of nitric acid concentrations and for applied DMDOHEMA concentrations. 


\section{Experimental}

Organic phases were solutions of DMDOHEMA (Panchim, France; previously purified over Alumina B) in TPH (Prochrom, France) at 0.50, 0.65, 0.75, and $1.0 \mathrm{~mol} / \mathrm{L}(241.0,313.3$, 361.5 , and $482.0 \mathrm{~g} / \mathrm{L})$. They were pre-contacted with water. Aqueous phases were either nitric acid or ${ }^{241} \mathrm{Am}$ (III) $\left(1 \mathrm{MBq} / \mathrm{L}, 3.3 \times 10^{-8} \mathrm{~mol} / \mathrm{L}\right)+{ }^{152} \mathrm{Eu}(\mathrm{III})\left(1.6 \mathrm{MBq} / \mathrm{L}, 1.6 \times 10^{-9} \mathrm{~mol} / \mathrm{L}\right)$ in nitric acid of varied concentration $(0.1-7 \mathrm{~mol} / \mathrm{L})$. Further experiments were carried out with aqueous phases additionally containing ${ }^{244} \mathrm{Cm}(\mathrm{III})\left(1 \mathrm{MBq} / \mathrm{L}, 1.4 \times 10^{-9} \mathrm{~mol} / \mathrm{L}\right)$ and stable lanthanide nitrates $(\mathrm{Ln}(\mathrm{III})=\mathrm{Y}(\mathrm{III}), \mathrm{La}(\mathrm{III})-\mathrm{Lu}(\mathrm{III})$ except $\mathrm{Pm}(\mathrm{III}))$ in concentrations of $7 \times 10^{-5} \mathrm{~mol} / \mathrm{L}$ each. Aqueous phases containing $\mathrm{Nd}\left(\mathrm{NO}_{3}\right)_{3}(\leq 0.3 \mathrm{~mol} / \mathrm{L})$ in $\mathrm{HNO}_{3}(3-$ $5 \mathrm{~mol} / \mathrm{L}$ ) were used to load the solvent.

Each $0.5 \mathrm{~mL}$ of organic and aqueous phases were contacted at $(295 \pm 1) \mathrm{K}$ on an orbital shaker (IKA KS 250) for $45 \mathrm{~min}$ and centrifuged. It had been verified by preliminary tests that this time by far was sufficient to attain equilibrium. Following centrifugation, phases were separated and taken for analysis.

${ }^{241} \mathrm{Am}$ and ${ }^{152} \mathrm{Eu}$ were determined on a gamma counter (Packard Cobra Auto-Gamma 5003) in both organic and aqueous samples. Lanthanides were determined by ICP-MS (Perkin-Elmer Elan 6100). ${ }^{241} \mathrm{Am}$ and ${ }^{244} \mathrm{Cm}$ were analysed by alpha spectrometry. For ICP-MS and alpha spectrometric analysis of organic samples, organic aliquots were stripped into dilute nitric acid with an appropriate $A / O$ ratio.

Initial and equilibrium nitric acid concentrations in aqueous samples were determined by duplicate titration with $0.1 \mathrm{~mol} / \mathrm{L} \mathrm{NaOH}$ on a Metrohm Titroprocessor. Titration was repeated whenever values did not agree within $2 \%$. To determine the nitric acid concentration in the organic samples, these were stripped into water with an appropriate phase ratio, $A / O=3-10$, which was then titrated as described above. Samples containing low amounts of nitric acid were titrated with $0.02 \mathrm{~mol} / \mathrm{L} \mathrm{NaOH}$. Preliminary experiments showed that TPH itself did not extract detectable concentrations of nitric acid.

Water concentration in organic phases was determined by Karl Fischer titration.

All experiments were performed in (at least) duplicate. Reported experimental data are mean values. Distribution data are reported in the Supplemental Information.

\section{Treatment of aqueous phase non-ideality}

Equilibrium models for the extraction of nitric acid and Am(III) were established using activities in the aqueous phase and concentrations in the organic phase. 
Molal activities were used in aqueous phases. Molar nitric acid concentration $c$ [mol/L] was converted to the molal concentration scale, $m\left[\mathrm{~mol} / \mathrm{kg} \mathrm{H}_{2} \mathrm{O}\right]$, according to ${ }^{52}$

$$
m=0.995 c+0.04 c^{2}
$$

Molal nitric acid concentration was then converted to molal activity using activity coefficients $\gamma_{i}\left(i=\mathrm{H}^{+}\right.$and $\left.\mathrm{NO}_{3}{ }^{-}\right)$calculated with the Specific Interaction Theory (SIT). ${ }^{53-54}$ To cover the range of nitric acid concentrations used in this work ( $\leq 7 \mathrm{~mol} / \mathrm{L}$ ), the SIT equation (see below) was extended using higher-order ion interaction coefficients $\varepsilon_{n}\left(\mathrm{H}^{+} / \mathrm{NO}_{3}{ }^{-}\right): \varepsilon_{1}=0.07, \varepsilon_{2}=$ $1.0 \times 10^{-4}, \varepsilon_{3}=-1.2 \times 10^{-4}$ :

$$
\lg \gamma_{i}=-z_{i}^{2} \frac{A \sqrt{I_{m}}}{1+B a_{i} \sqrt{I_{m}}}+\sum_{n=1}^{3} \varepsilon_{n} m^{n}
$$

For nitric acid, the molal ionic strength $I_{\mathrm{m}}$ is equal to the molal concentration $m$. The mean activity coefficient $\gamma_{ \pm}$is equal to the ionic activity coefficients, $\gamma\left(\mathrm{H}^{+}\right)$and $\gamma\left(\mathrm{NO}_{3}{ }^{-}\right)$. The ionic charges $z_{i}$ are 1 and -1 , respectively. $A$ and $B$ are constants, $a_{\mathrm{i}}$ is an ion size parameter.

Nitric acid activity coefficients for $0.1-9 \mathrm{~mol} / \mathrm{L} \mathrm{HNO}_{3}$ calculated accordingly agree within $\pm 3 \%$ with literature data. ${ }^{55-56}$

$\mathrm{Am}^{3+}$ activity was calculated by SIT, see above. A SIT coefficient of $\varepsilon\left(\mathrm{Am}^{3+} / \mathrm{NO}_{3}{ }^{-}\right)=0.27$ was used, as estimated from the literature. ${ }^{57-58}$

No corrections for non-ideality were performed in the organic phase.

\section{Results and discussion}

\section{Third phase formation}

When contacting aqueous phases with initial nitric acid concentrations up to $6 \mathrm{~mol} / \mathrm{L}$ with organic phases containing $0.5-1.0 \mathrm{~mol} / \mathrm{L}$ DMDOHEMA in TPH, no third phase occurred. However, when the initial nitric acid concentration was $7 \mathrm{~mol} / \mathrm{L}$, the formation of a third phase was observed with 0.50 and $0.75 \mathrm{~mol} / \mathrm{L}$ DMDOHEMA, but not with $1.0 \mathrm{~mol} / \mathrm{L}$ DMDOHEMA. These observations agree with results reported earlier. ${ }^{13,34,50}$

Loading an organic phase $(0.75 \mathrm{~mol} / \mathrm{L}$ DMDOHEMA in TPH) by extracting $\mathrm{Nd}(\mathrm{III})$ from an aqueous solution containing $\mathrm{Nd}\left(\mathrm{NO}_{3}\right)_{3}$ in $5 \mathrm{~mol} / \mathrm{L} \mathrm{HNO}_{3}$, third phase formation was observed for initial aqueous $\mathrm{Nd}(\mathrm{III})$ concentrations $\geq 0.1 \mathrm{~mol} / \mathrm{L}$. For $0.48 \mathrm{~mol} / \mathrm{L}$ and $0.62 \mathrm{~mol} / \mathrm{L}$ DMDOHEMA in TPH at $3 \mathrm{~mol} / \mathrm{L} \mathrm{HNO}_{3}$, third phase was observed for initial aqueous $\mathrm{Nd}$ (III) concentrations of $0.15 \mathrm{~mol} / \mathrm{L}$ and $0.2 \mathrm{~mol} / \mathrm{L}$, respectively. Organic phase $\mathrm{Nd}(\mathrm{III})$ 
concentrations were $0.082 \mathrm{~mol} / \mathrm{L}$ and $0.108 \mathrm{~mol} / \mathrm{L}$, respectively and aqueous phase $\mathrm{Nd}(\mathrm{III})$ concentrations were $0.074 \mathrm{~mol} / \mathrm{L}$ and $0.089 \mathrm{~mol} / \mathrm{L}$, respectively.

\section{Nitric acid extraction}

Similar to other neutral extracting agents, ${ }^{59-67}$ DMDOHEMA in TPH extracts significant amounts of nitric acid. Figure 2 shows the amount of nitric acid extracted as a function of initial aqueous nitric acid concentration (initial concentration is reported to represent nitric acid extraction for given experimental conditions, i. e. initial nitric acid and DMDOHEMA concentrations). E.g., for an initial aqueous nitric acid concentration of $5 \mathrm{~mol} / \mathrm{L}$, the organic equilibrium nitric acid concentration exceeds the total extracting agent concentration. Species such as $\left(\mathrm{HNO}_{3}\right)_{x} \mathrm{~L}$ (with $x>1$ ) must be present in the organic phase. This agrees with results from other studies with similar extracting agents. ${ }^{1,29-32}$ Details on the calculations (lines in Figure 2) are given in the section "Equilibrium model for nitric acid extraction" below.

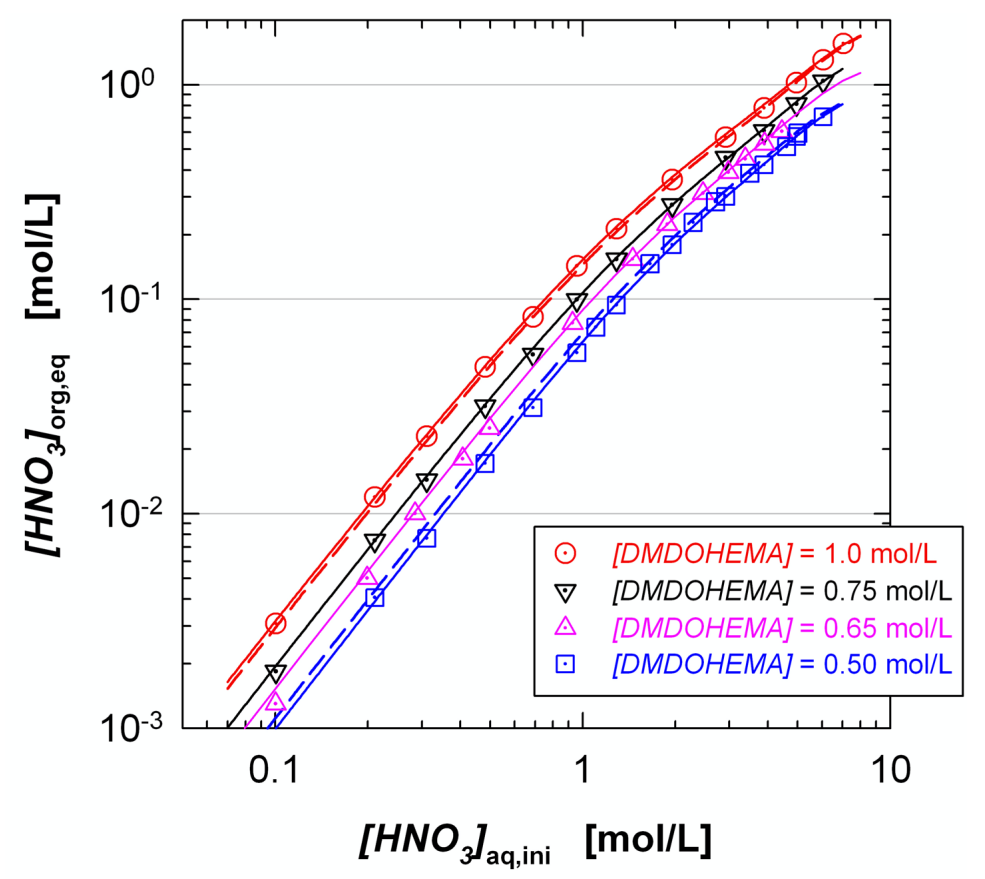

Figure 2. Extraction of nitric acid into DMDOHEMA in TPH. Equilibrium organic nitric acid concentration as a function of initial aqueous nitric acid concentration. Organic phase, DMDOHEMA in TPH. Aqueous phase, $\mathrm{HNO}_{3}$ or ${ }^{241} \mathrm{Am}(\mathrm{III})(1000 \mathrm{~Bq} / \mathrm{mL})+{ }^{152} \mathrm{Eu}(\mathrm{III})(1600 \mathrm{~Bq} / \mathrm{mL})$ in $\mathrm{HNO}_{3} . T=295 \mathrm{~K}$, $A / O=1$. Lines, calculated using fixed (dashed lines) or conditional (solid lines) extraction constants (see "Equilibrium model for nitric acid extraction"). See Table SI 1 for numerical values. 


\section{Extraction of americium(III) and europium(III)}

The distribution of Am(III) as a function of initial nitric acid concentration is shown in Figure 3. Am(III) is extracted (i.e., $D_{\mathrm{Am}(\mathrm{III})}>1$ ) from nitric acid with a concentration $>2 \mathrm{~mol} / \mathrm{L}$ (for $0.5 \mathrm{~mol} / \mathrm{L}$ DMDOHEMA) or $>1.5 \mathrm{~mol} / \mathrm{L}$ (for $1.0 \mathrm{~mol} / \mathrm{L}$ DMDOHEMA). Am(III) is backextracted (i.e., $D_{\mathrm{Am}(\mathrm{III})}<1$ ) into dilute nitric acid.

Details on the calculations (lines in Figure 3) are given in the section "Am(III) equilibrium model" below.
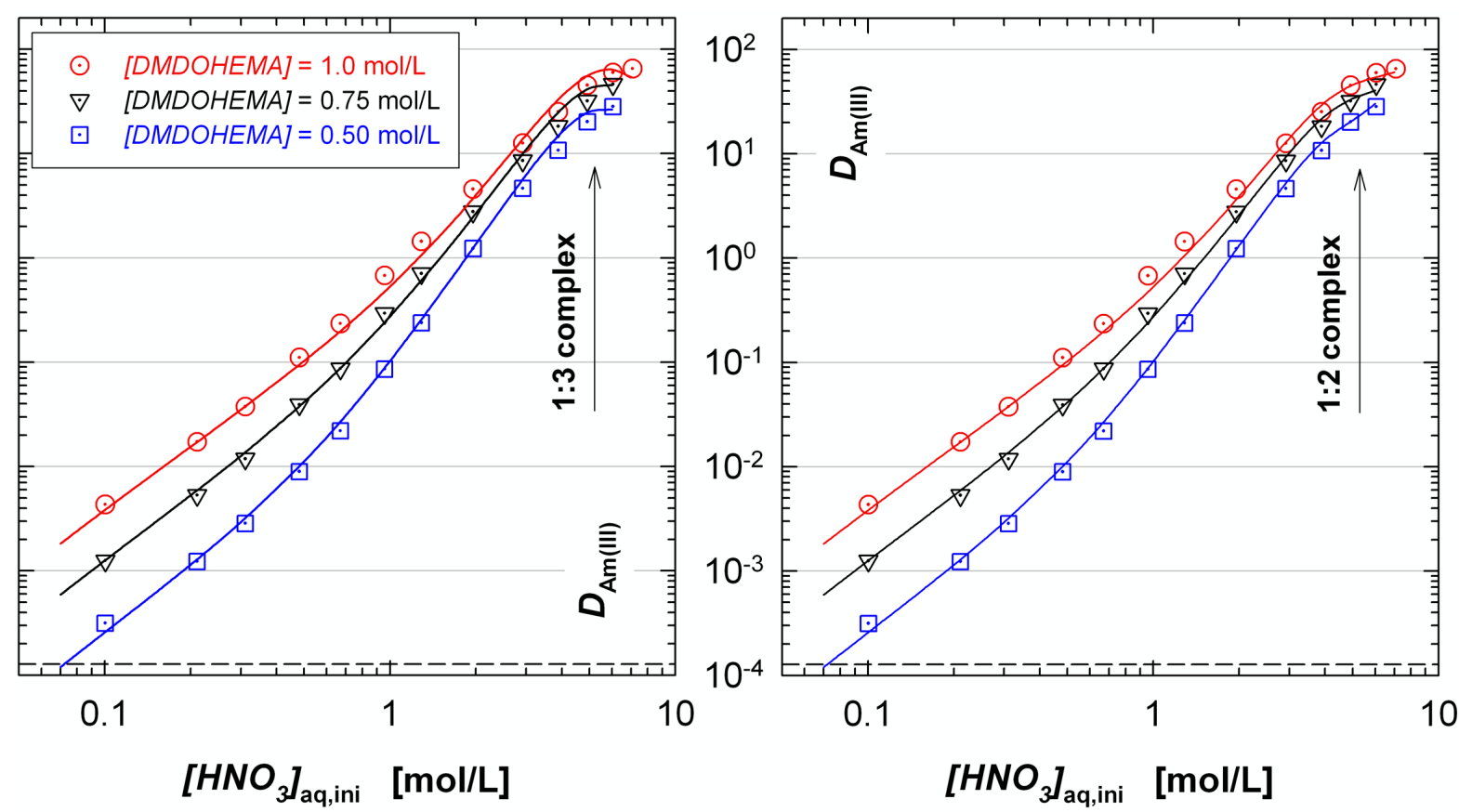

Figure 3. Extraction of Am(III) into DMDOHEMA in TPH. Distribution ratios as a function of initial aqueous nitric acid concentration. Organic phase, DMDOHEMA in TPH. Aqueous phase, ${ }^{241} \mathrm{Am}(\mathrm{III})$ $(1000 \mathrm{~Bq} / \mathrm{mL})+{ }^{152} \mathrm{Eu}(\mathrm{III})(1600 \mathrm{~Bq} / \mathrm{mL})$ in nitric acid. $T=295 \mathrm{~K}, A / O=1$. Dashed line, detection limit. Lines, calculated accounting for the $\mathrm{Am}\left(\mathrm{NO}_{3}\right)_{3}\left(\mathrm{HNO}_{3}\right)_{2} \mathbf{L}_{3}$ complex (left) or the $\mathrm{Am}\left(\mathrm{NO}_{3}\right)_{3}\left(\mathrm{HNO}_{3}\right)_{2} \mathbf{L}_{2}$ complex (right), see "Am(III) equilibrium model”. See Table SI 1 for numerical values.

The experiments shown in Figure 2 and Figure 3 also contained ${ }^{152} \mathrm{Eu}(\mathrm{III})$. Figure 4 shows the respective $\mathrm{Eu}(\mathrm{III})$ distribution ratios (reported as $\mathrm{Am}(\mathrm{III}) / \mathrm{Eu}(\mathrm{III})$ separation factors, $\left.S F_{\mathrm{Am}(\mathrm{III}) / \mathrm{Eu}(\mathrm{III})}=D_{\mathrm{Am}(\mathrm{III})} / D_{\mathrm{Eu}(\mathrm{III})}\right)$. Since the DMDOHEMA concentration did not show a significant or systematic effect on the separation factor, all values for a given nitric acid concentration were averaged. 


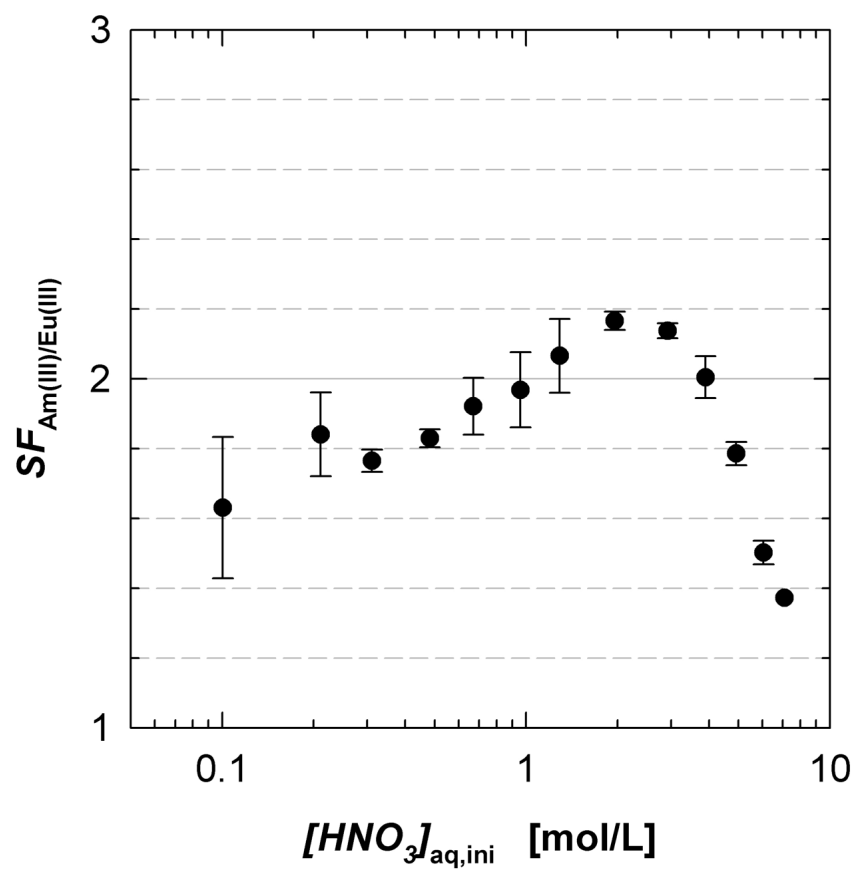

Figure 4. $\mathrm{Am}(\mathrm{III}) / \mathrm{Eu}(\mathrm{III})$ separation factor as a function of initial aqueous nitric acid concentration. Organic phase, $(0.5-1.0 \mathrm{~mol} / \mathrm{L})$ DMDOHEMA in TPH. Aqueous phase, ${ }^{241} \mathrm{Am}(\mathrm{III})(1000 \mathrm{~Bq} / \mathrm{mL})+$ ${ }^{152} \mathrm{Eu}(\mathrm{III})(1600 \mathrm{~Bq} / \mathrm{mL})$ in nitric acid. $T=295 \mathrm{~K}, A / O=1$. See Table SI 1 for numerical values.

The $S F_{\mathrm{Am}(\mathrm{III}) / \mathrm{Eu}(\mathrm{III})}$ values are in the range of $1.8 \pm 0.4$. The slight variation of $S F_{\mathrm{Am}(\mathrm{III}) / \mathrm{Eu}(\mathrm{III})}$ values with nitric acid concentration appears to have a systematic trend which may originate from small differences in organic phase or aqueous phase speciation of Am(III) vs. Eu(III).

\section{Extraction of curium(III) and lanthanides(III)}

Further to the extraction of nitric acid, Am(III) and $\mathrm{Eu}(\mathrm{III})$, the extraction of $\mathrm{Cm}(\mathrm{III})$, lanthanides(III) $(\mathrm{Ln}(\mathrm{III})=\mathrm{La}-\mathrm{Lu}$ except $\mathrm{Pm})$ and $\mathrm{Y}(\mathrm{III})$ was studied as these are the major species to be extracted in DIAMEX or similar processes.

Figure 5 shows distribution ratios for a DMDOHEMA concentration of $0.75 \mathrm{~mol} / \mathrm{L}$ as a function of initial nitric acid concentration (0.11-3.0 mol/L). Results from a second experiment using a DMDOHEMA concentration of $1.0 \mathrm{~mol} / \mathrm{L}$ and nitric acid concentrations of $2.6-6.1 \mathrm{~mol} / \mathrm{L}$ are shown in Figure 6 . The respective separation factors $\left(S F_{\mathrm{Am}(\mathrm{III}) / \mathrm{M}(\mathrm{III})}=\right.$ $\left.D_{\mathrm{Am}(\mathrm{III})} / D_{\mathrm{M}(\mathrm{III})}\right)$ for Am(III) over M(III) (M = curium, yttrium and all lanthanides except promethium) are reported in Table 1. 

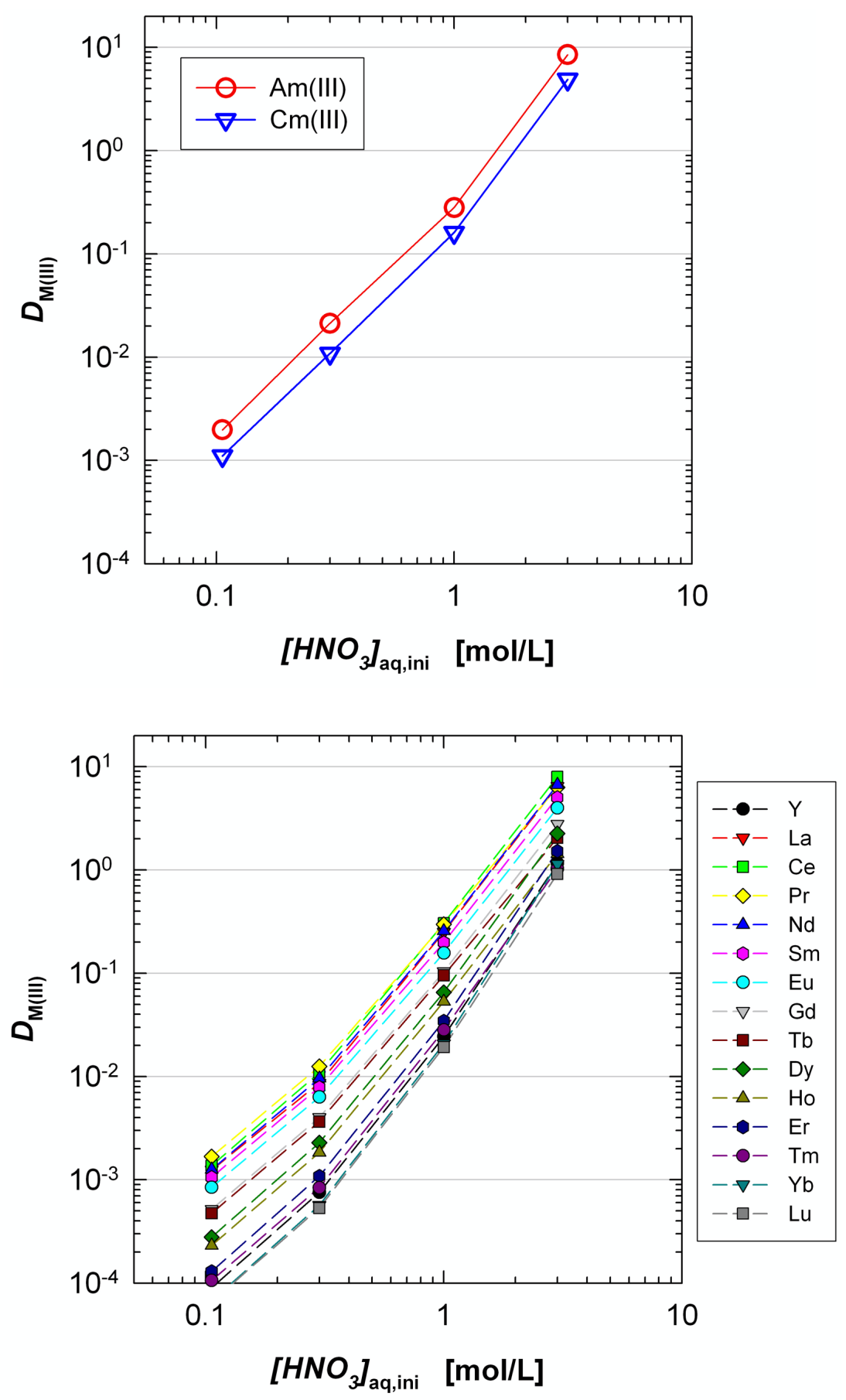

Figure 5. Extraction of Am(III), Cm(III), Y(III) and Ln(III) into DMDOHEMA in TPH. Distribution ratios as a function of initial aqueous nitric acid concentration. Top, Am(III) and Cm(III). Bottom, Ln(III) and Y(III). Organic phase, $0.75 \mathrm{~mol} / \mathrm{L}$ DMDOHEMA in TPH. Aqueous phase, ${ }^{241} \mathrm{Am}(\mathrm{III})(1000 \mathrm{~Bq} / \mathrm{mL})+$ ${ }^{244} \mathrm{Cm}(\mathrm{III})(1000 \mathrm{~Bq} / \mathrm{mL})+{ }^{152} \mathrm{Eu}(\mathrm{IIII})(1600 \mathrm{~Bq} / \mathrm{mL})+\mathrm{Ln}(\mathrm{III})$ and $\mathrm{Y}(\mathrm{III})\left(7 \times 10^{-5} \mathrm{~mol} / \mathrm{L}\right.$ each $)$ in nitric acid. $T=295 \mathrm{~K}, A / O=1$. 


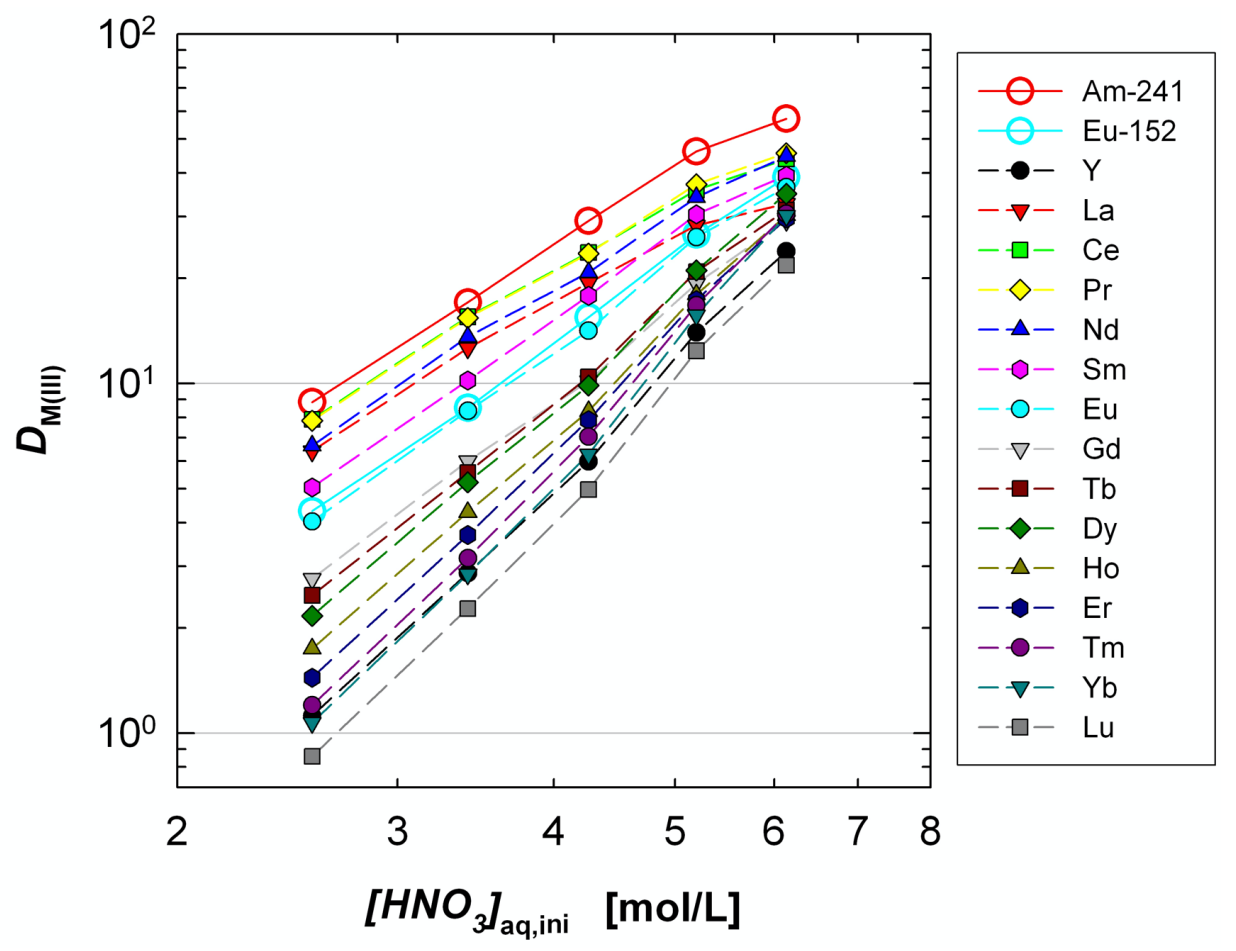

Figure 6. Extraction of $\mathrm{Am}(\mathrm{III}), \mathrm{Ln}(\mathrm{III})$ and $\mathrm{Y}(\mathrm{III})$ into DMDOHEMA in TPH. Distribution ratio as a function of initial aqueous nitric acid concentration. Organic phase, $1.0 \mathrm{~mol} / \mathrm{L}$ DMDOHEMA in TPH. Aqueous phase, ${ }^{241} \mathrm{Am}(\mathrm{III})(1000 \mathrm{~Bq} / \mathrm{mL})+{ }^{152} \mathrm{Eu}(\mathrm{III})(1600 \mathrm{~Bq} / \mathrm{mL})+\mathrm{Ln}(\mathrm{III})$ and $\mathrm{Y}(\mathrm{III})\left(7 \times 10^{-5} \mathrm{~mol} / \mathrm{L}\right.$ each) in nitric acid. $T=295 \mathrm{~K}, A / O=1$.

The $\mathrm{Am}(\mathrm{III}) / \mathrm{Cm}(\mathrm{III})$ selectivity $\left(S F_{\mathrm{Am}(\mathrm{III}) / \mathrm{Cm}(\mathrm{III})} \approx 1.8\right)$ agrees reasonably well with data reported in the literature $\left(S F_{\mathrm{Am}(\mathrm{III}) / \mathrm{Cm}(\mathrm{III})} \approx 1.6\right) .{ }^{68}$ The extractability of the lanthanides(III) decreases with their atomic number, as observed earlier. ${ }^{39} \mathrm{Cm}$ (III) behaves similar to $\mathrm{Sm}(\mathrm{III})$, $\mathrm{Y}(\mathrm{III})$ behaves similar to $\mathrm{Tm}(\mathrm{III})$ and $\mathrm{Yb}$ (III). That is, affinity is primarily driven by the size of the respective trivalent metal ions, in agreement with results from other extracting agents such as HDEHP ${ }^{69}$ or TODGA. ${ }^{70}$

Separation factors for $\mathrm{Am}$ (III) over $\mathrm{Cm}$ (III) and the lighter lanthanides(III) (up to $\mathrm{Tb}$ (III)) are practically independent of nitric acid concentration. However, the separation factors decrease with increasing nitric acid concentration for the heavier lanthanides(III), in particular for Er(III) and heavier Ln(III). This behaviour could be due to differences in aqueous or organic phase speciation. Generally, distribution data for An(III) and Ln(III) are in agreement with the scarce data reported in the literature. ${ }^{13,34,71-72}$ 
Table 1. Extraction of $\mathrm{Am}(\mathrm{III}), \mathrm{Cm}(\mathrm{III}), \mathrm{Y}(\mathrm{III})$ and lanthanides(III) into DMDOHEMA in TPH. $\mathrm{Am}(\mathrm{III}) / \mathrm{M}(\mathrm{III})$ separation factors as a function of initial aqueous nitric acid concentration. Experimental conditions, see Figure 5 and Figure 6. $S F_{\mathrm{Am} \text { (III)/Cm(III) }}$ from alpha spectroscopy data, $S F_{\mathrm{Am}(\mathrm{III}) / \mathrm{Eu}(\mathrm{III})-152}$ from gamma spectroscopy data, all other values from Am(III) gamma spectroscopy and Ln(III) ICP-MS data.

\begin{tabular}{|c|ccccccccc|}
\hline \multirow{2}{*}{$\boldsymbol{S F}_{\mathbf{A m}(\mathbf{I I I}) / \mathbf{M}(\mathbf{I I I})}$} & $\mathbf{0 . 1 1}$ & $\mathbf{0 . 3 0}$ & $\mathbf{1 . 0}$ & $\mathbf{2 . 6}$ & $\mathbf{3 . 0}$ & $\mathbf{3 . 4}$ & $\mathbf{4 . 3}$ & $\mathbf{5 . 2}$ & $\mathbf{6 . 1}$ \\
\hline $\mathrm{Cm}$ & 1.8 & 2.0 & 1.8 & - & 1.7 & - & - & - & - \\
$\mathrm{Y}$ & 18 & 16 & 13 & 7.9 & 7.4 & 5.9 & 4.9 & 3.3 & 2.4 \\
$\mathrm{La}$ & 1.4 & 1.4 & 1.3 & 1.4 & 1.3 & 1.4 & 1.5 & 1.6 & 1.7 \\
$\mathrm{Ce}$ & 1.2 & 1.1 & 1.1 & 1.1 & 1.1 & 1.1 & 1.2 & 1.3 & 1.3 \\
$\mathrm{Pr}$ & 1.0 & 1.0 & 1.1 & 1.1 & 1.4 & 1.1 & 1.2 & 1.2 & 1.3 \\
$\mathrm{Nd}$ & 1.3 & 1.3 & 1.3 & 1.3 & 1.3 & 1.3 & 1.4 & 1.4 & 1.3 \\
$\mathrm{Sm}$ & 1.6 & 1.6 & 1.6 & 1.8 & 1.7 & 1.7 & 1.6 & 1.5 & 1.5 \\
$\mathrm{Eu}$ & 2.0 & 1.9 & 2.1 & 2.2 & 2.2 & 2.0 & 2.1 & 1.8 & 1.6 \\
$\mathrm{Eu}-152$ & 1.9 & 1.8 & 2.1 & 2.1 & 2.1 & 2.0 & 1.9 & 1.7 & 1.5 \\
$\mathrm{Gd}$ & 3.2 & 3.1 & 3.1 & 3.2 & 3.0 & 2.8 & 2.9 & 2.4 & 2.0 \\
$\mathrm{~Tb}$ & 3.6 & 3.4 & 3.4 & 3.6 & 4.2 & 3.1 & 2.8 & 2.2 & 1.8 \\
$\mathrm{Dy}$ & 6.0 & 5.4 & 5.0 & 4.1 & 3.8 & 3.3 & 3.0 & 2.2 & 1.6 \\
$\mathrm{Ho}$ & 7.3 & 6.7 & 6.1 & 5.1 & 6.0 & 4.0 & 3.5 & 2.6 & 1.9 \\
$\mathrm{Er}$ & 13 & 11 & 9.4 & 6.1 & 5.6 & 4.6 & 3.7 & 2.7 & 1.9 \\
$\mathrm{Tm}$ & 16 & 15 & 12 & 7.4 & 8.3 & 5.4 & 4.1 & 2.8 & 1.9 \\
$\mathrm{Yb}$ & 25 & 22 & 16 & 8.0 & 7.5 & 6.0 & 4.6 & 2.9 & 1.9 \\
$\mathrm{Lu}$ & 25 & 23 & 17 & 10 & 9.4 & 7.5 & 5.9 & 3.7 & 2.6 \\
\hline
\end{tabular}

\section{Equilibrium model for nitric acid extraction}

Based on the experimental results (Figure 2) and concluding from earlier studies, ${ }^{1,29-32}$ nitric acid extraction by DMDOHEMA was calculated taking into account the formation of three adducts, $\left(\mathrm{HNO}_{3}\right) \mathrm{L}_{2}$, $\left(\mathrm{HNO}_{3}\right) \mathrm{L}$ and $\left(\mathrm{HNO}_{3}\right)_{2} \mathrm{~L}$. Hydrated species were not considered since non-stoichiometric or weak interactions seem to prevail in the case of malonamides or similar systems, see references ${ }^{1,29-31}$ and Table SI 1 . The following extraction constants were used, with activities in the aqueous phase and concentrations in the organic phase:

$$
\begin{aligned}
K_{\mathrm{H} 12} & =\frac{\left[\left(\mathrm{HNO}_{3}\right) \mathrm{L}_{2}\right]}{\left(\mathrm{H}^{+}\right) \cdot\left(\mathrm{NO}_{3}^{-}\right) \cdot[\mathrm{L}]^{2}} \\
K_{\mathrm{H} 11} & =\frac{\left[\left(\mathrm{HNO}_{3}\right) \mathrm{L}\right]}{\left(\mathrm{H}^{+}\right) \cdot\left(\mathrm{NO}_{3}^{-}\right) \cdot[\mathrm{L}]} \\
K_{\mathrm{H} 21} & =\frac{\left[\left(\mathrm{HNO}_{3}\right)_{2} \mathrm{~L}\right]}{\left(\mathrm{H}^{+}\right)^{2} \cdot\left(\mathrm{NO}_{3}^{-}\right)^{2} \cdot[\mathrm{L}]}
\end{aligned}
$$


This model allows describing the extraction of nitric acid without accounting for aggregation equilibria. With these equations, equilibrium aqueous activities and organic concentrations were calculated, the organic equilibrium nitric acid concentration $\left[\mathrm{HNO}_{3}\right]_{\mathrm{org}, \mathrm{eq}}$ being

$$
\left[\mathrm{HNO}_{3}\right]_{\mathrm{org}, \mathrm{eq}}=\left[\left(\mathrm{HNO}_{3}\right)_{2}\right]+\left[\left(\mathrm{HNO}_{3}\right) \mathrm{L}\right]+2\left[\left(\mathrm{HNO}_{3}\right)_{2} \mathrm{~L}\right]
$$

and the free DMDOHEMA concentration $[L]$,

$$
[L]=[L]_{\text {total }}-\left(2\left[\left(\mathrm{HNO}_{3}\right) L_{2}\right]+\left[\left(\mathrm{HNO}_{3}\right) L\right]+\left[\left(\mathrm{HNO}_{3}\right)_{2} \mathrm{~L}\right]\right)
$$

Initially, a set of three extraction constants independent of the total extracting agent concentration was used,

$$
\begin{aligned}
& K_{\mathrm{H} 12}=0.27 \mathrm{~kg}^{2} \mathrm{~L} \mathrm{~mol}^{-3} \\
& K_{\mathrm{H} 11}=0.23 \mathrm{~kg}^{2} \mathrm{~mol}^{-2} \\
& K_{\mathrm{H} 21}=0.003 \mathrm{~kg}^{4} \mathrm{~mol}^{-4}
\end{aligned}
$$

The results from the calculations are shown as dashed lines in Figure 2. The constants were fit to the experimental data at $[D M D O H E M A]=0.75 \mathrm{~mol} / \mathrm{L}$, resulting in excellent agreement. However, nitric acid extraction is overestimated $(\approx 10 \%)$ for $0.50 \mathrm{~mol} / \mathrm{L}$ DMDOHEMA and underestimated $(\approx 5 \%)$ for $1.0 \mathrm{~mol} / \mathrm{L}$ DMDOHEMA. Within this accuracy, these constants are valid for technically relevant DMDOHEMA concentrations (other than those reported, ${ }^{45}$ where the extraction constants are valid for $[D M D O H E M A] \leq 0.1 \mathrm{~mol} / \mathrm{L}$ ).

Calculations using conditional extraction constants were performed to improve accuracy. Very good agreement with the experimental data is achieved using a fixed value for $K_{\mathrm{H} 12}$ and conditional extraction constants $K_{\mathrm{H} 11}$ and $K_{\mathrm{H} 21}$,

$$
\begin{aligned}
& K_{\mathrm{H} 12}=0.27 \mathrm{~kg}^{2} \mathrm{~L} \mathrm{~mol}^{-3} \\
& K_{\mathrm{H} 11}=(0.23+([L]-0.75) \times 0.16) \mathrm{kg}^{2} \mathrm{~mol}^{-2} \\
& K_{\mathrm{H} 21}=(0.003+([L]-0.75) \times 0.0032) \mathrm{kg}^{4} \mathrm{~mol}^{-4}
\end{aligned}
$$

Organic phase nitric acid concentrations calculated with these values are shown as solid lines in Figure 2. The standard deviation between calculated and experimental values is $2 \%$ (which is in the range of the experimental uncertainty).

The calculated species distribution for a total DMDOHEMA concentration of $0.75 \mathrm{~mol} / \mathrm{L}$ is shown in Figure 7. According to the calculations, nitric acid is mainly extracted as the 1:1 adduct, $\left(\mathrm{HNO}_{3}\right) \mathrm{L}$, and the 1:2 adduct, $\left(\mathrm{HNO}_{3}\right) \mathrm{L}_{2}$. The 2:1 adduct, $\left(\mathrm{HNO}_{3}\right)_{2} \mathrm{~L}$, dominates 
beyond an initial aqueous nitric acid concentration of $5 \mathrm{~mol} / \mathrm{L}$. The speciation is quite similar to that reported for DMDBTDMA, ${ }^{31}$ except that the formation of the $3: 1$ adduct, $\left(\mathrm{HNO}_{3}\right)_{3} \mathrm{~L}$, does not need to be considered in the case of DMDOHEMA. Despite the presence of water molecules in the organic phase (see Annex), the introduction of complexes including water was not necessary to represent nitric acid extraction.

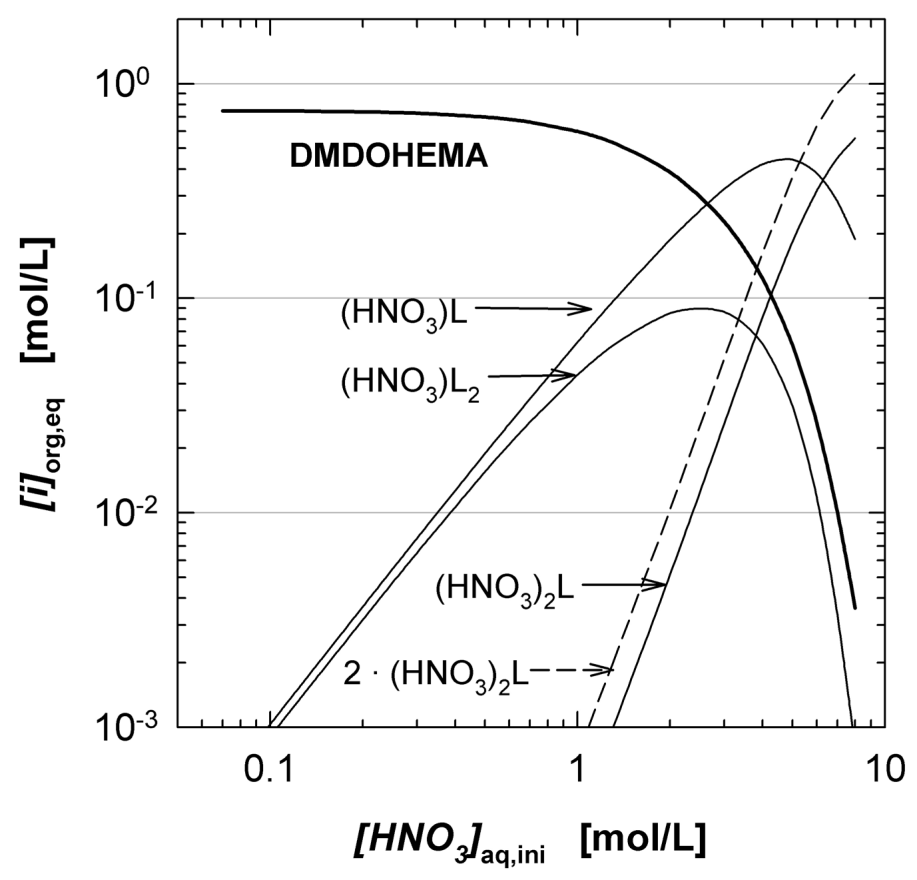

Figure 7. Extraction of nitric acid into $0.75 \mathrm{~mol} / \mathrm{L}$ DMDOHEMA in TPH. Calculated organic phase speciation as a function of initial aqueous nitric acid concentration. Dashed line is twice the concentration of the $\left(\mathrm{HNO}_{3}\right)_{2} \mathrm{~L}$ adduct, representing its contribution to the organic phase nitric acid concentration.

\section{Equilibrium model for americium(III) extraction}

Considering results from slope analysis (see below) based on the Am(III) distribution data presented in Figure 3 and on spectroscopy results, ${ }^{43}$ an equilibrium model for the extraction of Am(III) was established.

\section{Stoichiometry of Am(III)-DMDOHEMA complexes}

The slopes of $\lg D_{\mathrm{Am}(\mathrm{III})}$ vs. $\lg \left[\mathrm{HNO}_{3}\right]_{\mathrm{aq}, \text { eq }}$ (as derived from Figure 3 ) have values of 3.1, 2.8 and 2.6 (for $0.5,0.75$, and $1.0 \mathrm{~mol} / \mathrm{L}$ DMDOHEMA). This must not be interpreted assuming the formation of a complex, $\mathrm{Am}\left(\mathrm{NO}_{3}\right)_{3} \mathrm{~L}_{n}$. In fact, such a simple slope analysis is not valid since the free DMDOHEMA concentration varies significantly with nitric acid concentration due to the pronounced nitric acid extraction. 
A more elaborate approach is required. To determine the number of DMDOHEMA molecules in the extracted complexes, Am(III) distribution ratios were plotted versus the free DMDOHEMA concentration at constant nitrate activity. Similarly, the number of nitrate anions was determined by plotting Am(III) distribution ratios versus equilibrium nitrate activity at a constant free DMDOHEMA concentration. In detail:

The number of DMDOHEMA molecules was determined by plotting $\lg D_{\text {Am(III) }}$ versus $\lg [D M D O H E M A]_{\mathrm{eq}}$ at constant $\left[\mathrm{HNO}_{3}\right]_{\mathrm{aq}, \mathrm{eq}}$ (and hence, constant $\left(\mathrm{NO}_{3}^{-}\right)_{\mathrm{aq}, \mathrm{eq}}$ ). The free equilibrium DMDOHEMA concentration was calculated with the model reported above, using conditional $K_{\mathrm{H} 11}$ and $K_{\mathrm{H} 21}$ values. Am(III) distribution ratios at given aqueous equilibrium nitric acid concentrations were determined by plotting $\lg D_{\mathrm{Am} \text { (III) }}$ versus $\lg \left[\mathrm{HNO}_{3}\right]_{\mathrm{aq} \text {,eq }}$ and reading out interpolated $\mathrm{D}_{\mathrm{Am} \text { (III) }}$ at constant $\left[\mathrm{HNO}_{3}\right]_{\mathrm{aq} \text {,eq. }}$ Finally, these $\lg D_{\mathrm{Am}(\mathrm{III})}$ values were plotted versus $\lg [D M D O H E M A]_{\mathrm{eq}}$. The resulting slopes are reported in Table 2. The values of the slopes are close to four in the nitric acid concentration range of $0.1-1 \mathrm{~mol} / \mathrm{L}$, decreasing to values around three $\left(2-3 \mathrm{~mol} / \mathrm{L} \mathrm{HNO}_{3}\right)$ and finally around two $\left(\geq 5 \mathrm{~mol} / \mathrm{L} \mathrm{HNO}_{3}\right.$ ). These slopes insinuate a complex containing four DMDOHEMA molecules is dominant at lower nitric acid concentration, whereas complexes with three or two DMDOHEMA molecules become dominating with increasing acidity.

Table 2. Slopes for $\lg D_{\mathrm{Am} \text { (III) }}$ versus $\lg [D M D O H E M A]_{\mathrm{eq}}$ at a function of equilibrium nitric acid concentration.

\begin{tabular}{|c|ccccccccccc|}
\hline [HNO $\left._{3}\right]_{\text {aq,eq }}[\mathrm{mol} / \mathbf{L}]$ & 0.10 & 0.20 & 0.30 & 0.50 & 0.70 & 1.00 & 1.50 & 2.00 & 3.00 & 4.00 & 5.00 \\
\hline Slope & 3.9 & 4.0 & 4.0 & 4.1 & 4.0 & 3.8 & 3.5 & 3.1 & 2.8 & 2.6 & 2.2 \\
\hline
\end{tabular}

In a similar fashion, $\lg \left([\mathrm{Am}(\mathrm{III})]_{\mathrm{org}} /\left(\mathrm{Am}^{3+}\right)_{\mathrm{aq}}\right)$ was plotted versus $\lg \left(\mathrm{NO}_{3}{ }^{-}\right)_{\text {aq,eq }}$ at constant $[D M D O H E M A]_{\text {eq }}$ (calculated as above). The slopes' values were found to increase with increasing $\left(\mathrm{NO}_{3}{ }^{-}\right)_{\text {aq,eq }}$ from approximately three to approximately five, see Figure 8 . Slopes having values greater than three may be explained by the presence of complexes containing additional nitric acid molecules. 


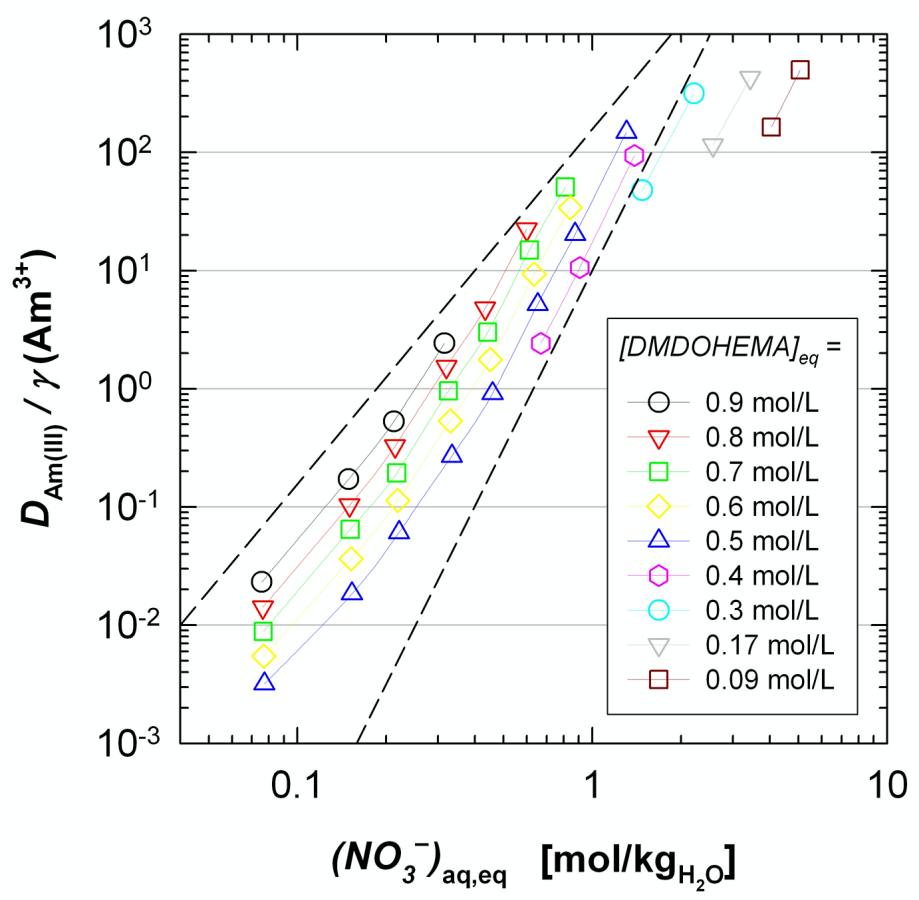

Figure 8. Am(III) distribution ratios corrected for $\mathrm{Am}^{3+}$ activity coefficients as a function of equilibrium nitrate activity at constant free DMDOHEMA concentration (as indicated in legend). Dashed lines, slopes 3 and 5 .

The slopes from Table 2 and Figure 8, together with published results, ${ }^{2,37}$ indicate the formation of three complexes, $\mathrm{Am}\left(\mathrm{NO}_{3}\right)_{3} \mathrm{~L}_{4}, \mathrm{Am}\left(\mathrm{NO}_{3}\right)_{3}\left(\mathrm{HNO}_{3}\right) \mathrm{L}_{3}$ and $\mathrm{Am}\left(\mathrm{NO}_{3}\right)_{3}\left(\mathrm{HNO}_{3}\right)_{2} \mathrm{~L}_{2}$. Indeed, there is spectroscopic evidence for the presence of complexes containing four and three DMDOHEMA molecules at low and intermediate nitric acid concentrations, respectively. ${ }^{43}$ However, this study did not identify a complex containing two DMDOHEMA molecules for nitric acid concentrations $\leq 6 \mathrm{~mol} / \mathrm{L} \mathrm{HNO}_{3}$.

The change in stoichiometry with increasing nitric acid concentration is similar to changes observed in the $\mathrm{Eu}$ (III) complexes with increasing $\mathrm{Eu}$ (III) concentration. ${ }^{42}$ It is also consistent with data indicating increasing aggregation with increasing acidity (i. e. decreasing critical aggregation concentration). ${ }^{51}$ Extraction of nitric acid results in the formation of larger, more hydrated aggregates containing nitric acid molecules in the polar core. This could explain the change in the stoichiometry from $\mathrm{M}\left(\mathrm{NO}_{3}\right)_{3} \mathrm{~L}_{4}$ at low nitric acid concentration to $\mathrm{M}\left(\mathrm{NO}_{3}\right)_{3}\left(\mathrm{HNO}_{3}\right)_{2} \mathrm{~L}_{2}$ at elevated nitric acid concentrations.

\section{Am(III) equilibrium model}

Based on slope analysis and/or spectroscopy results, ${ }^{43}$ two equilibrium models for the extraction of Am(III) were developed and compared. Additionally to the nitric acid adducts 
(see above), the following complexes were taken into account, $\mathrm{Am}\left(\mathrm{NO}_{3}\right)_{3} \mathrm{~L}_{4}$, $\mathrm{Am}\left(\mathrm{NO}_{3}\right)_{3}\left(\mathrm{HNO}_{3}\right) \mathrm{L}_{3}$ and a third complex: $\mathrm{Am}\left(\mathrm{NO}_{3}\right)_{3}\left(\mathrm{HNO}_{3}\right)_{2} \mathbf{L}_{3}$ (considering the spectroscopic results ${ }^{43}$ that indicated the absence of a complex containing two DMDOHEMA molecules) or $\mathrm{Am}\left(\mathrm{NO}_{3}\right)_{3}\left(\mathrm{HNO}_{3}\right)_{2} \mathbf{L}_{2}$ (considering slope analysis results, see Table 2 ) with the respective extraction constants,

$$
\begin{aligned}
& \text { - } \quad K_{\mathrm{Am} 34}=\frac{\left[\mathrm{Am}\left(\mathrm{NO}_{3}\right)_{3} \mathrm{~L}_{4}\right]}{\left(\mathrm{Am}^{3+}\right) \cdot\left(\mathrm{NO}_{3}^{-}\right)^{3} \cdot[L]^{4}}=75 \\
& \text { - } \quad K_{\mathrm{Am} 43}=\frac{\left[\mathrm{Am}\left(\mathrm{NO}_{3}\right)_{3}\left(\mathrm{HNO}_{3}\right) \mathrm{L}_{3}\right]}{\left(\mathrm{Am}^{3+}\right) \cdot\left(\mathrm{H}^{+}\right) \cdot\left(\mathrm{NO}_{3}^{-}\right)^{4} \cdot[\mathrm{L}]^{3}}=220 \\
& \text { - } \quad K_{\mathrm{Am} 53}=\frac{\left[\mathrm{Am}\left(\mathrm{NO}_{3}\right)_{3}\left(\mathrm{HNO}_{3}\right)_{2} \mathrm{~L}_{3}\right]}{\left(\mathrm{Am}^{3+}\right) \cdot\left(\mathrm{H}^{+}\right)^{2} \cdot\left(\mathrm{NO}_{3}^{-}\right)^{5} \cdot[\mathrm{L}]^{3}}=3 \\
& \text { or } \\
& K_{\mathrm{Am} 52}=\frac{\left[\mathrm{Am}\left(\mathrm{NO}_{3}\right)_{3}\left(\mathrm{HNO}_{3}\right)_{2} \mathrm{~L}_{2}\right]}{\left(\mathrm{Am}^{3+}\right) \cdot\left(\mathrm{H}^{+}\right)^{2} \cdot\left(\mathrm{NO}_{3}^{-}\right)^{5} \cdot[\mathrm{L}]^{2}}=0.06
\end{aligned}
$$

Am(III) distribution ratios as a function of nitric acid and DMDOHEMA concentrations were calculated with either model. In any case, conditional constants for nitric acid extraction (Figure 2) were used. Using fixed constants for nitric acid extraction resulted in substantial deviations between calculated and experimental Am(III) distribution ratios for nitric acid concentrations greater than $3 \mathrm{~mol} / \mathrm{L}$.

Am(III) distribution ratios calculated accounting for the $\mathrm{Am}\left(\mathrm{NO}_{3}\right)_{3}\left(\mathrm{HNO}_{3}\right)_{2} \mathbf{L}_{3}$ complex (Figure 3 left) or the $\mathrm{Am}\left(\mathrm{NO}_{3}\right)_{3}\left(\mathrm{HNO}_{3}\right)_{2} \mathbf{L}_{2}$ complex (Figure 3 right), respectively, are compared to experimental distribution data.

For nitric acid concentrations less than $3 \mathrm{~mol} / \mathrm{L}$, the calculations agree with experimental values within approx. $10 \%$, with the exception of the calculations for $1 \mathrm{~mol} / \mathrm{L}$ DMDOHEMA and $0.5-2 \mathrm{~mol} / \mathrm{L} \mathrm{HNO}_{3}$. For nitric acid concentrations greater than $3 \mathrm{~mol} / \mathrm{L}$, the model accounting for the $\mathrm{Am}\left(\mathrm{NO}_{3}\right)_{3}\left(\mathrm{HNO}_{3}\right)_{2} \mathbf{L}_{2}$ complex (Figure 3 right) performs slightly better than the model accounting for the $\mathrm{Am}\left(\mathrm{NO}_{3}\right)_{3}\left(\mathrm{HNO}_{3}\right)_{2} \mathbf{L}_{3}$ complex (Figure 3 left).

The contribution of the individual Am(III)-DMDOHEMA complexes to the extraction of $\mathrm{Am}(\mathrm{III})$ is shown in Figure 9. According to the calculations, $\mathrm{Am}\left(\mathrm{NO}_{3}\right)_{3} \mathrm{~L}_{4}$ is the predominant complex for initial nitric acid concentrations smaller than $0.7 \mathrm{~mol} / \mathrm{L}$. $\mathrm{Am}\left(\mathrm{NO}_{3}\right)_{3}\left(\mathrm{HNO}_{3}\right) \mathrm{L}_{3}$ is the dominating complex in the concentration range of $0.7-6 \mathrm{~mol} / \mathrm{L} \mathrm{HNO}_{3}$. The third complex (either $\mathrm{Am}\left(\mathrm{NO}_{3}\right)_{3}\left(\mathrm{HNO}_{3}\right)_{2} \mathbf{L}_{2}$ or $\mathrm{Am}\left(\mathrm{NO}_{3}\right)_{3}\left(\mathrm{HNO}_{3}\right)_{2} \mathbf{L}_{3}$, depending on the model used) plays a role only for nitric acid concentrations beyond $6 \mathrm{~mol} / \mathrm{L}$. Since this concentration is close to the limit of third phase formation, no further distinction can be made by measuring Am(III) distribution ratios at nitric acid concentrations beyond $6 \mathrm{~mol} / \mathrm{L}$. 


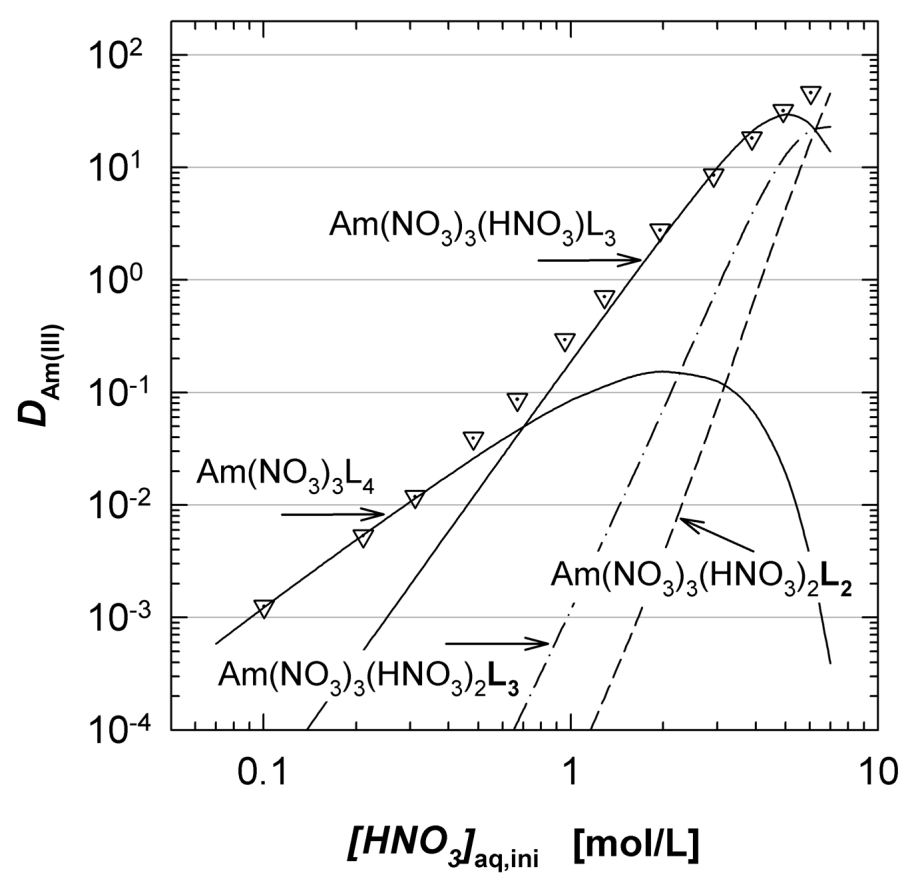

Figure 9. Am(III) extraction, contribution of the individual Am(III)-DMDOHEMA complexes. $0.75 \mathrm{~mol} / \mathrm{L}$ DMDOHEMA.

\section{Loading experiments}

A Ce(III) loading experiment performed at approximately $3 \mathrm{~mol} / \mathrm{L}$ nitric acid ${ }^{39}$ supports the formation of a 1:3 complex, in agreement with results from spectroscopy ${ }^{43}$ and slope analysis (Table 2). To help discriminating the formation of a 1:2 complex and a 1:3 complex at nitric acid concentrations $\geq 4 \mathrm{~mol} / \mathrm{L}$ (see Figure 3), a $\mathrm{Nd}$ (III) loading experiment was performed at an initial nitric acid concentration of $5 \mathrm{~mol} / \mathrm{L}$. Unfortunately, third phase formation was observed for initial aqueous $\mathrm{Nd}(\mathrm{III})$ concentrations $\geq 0.1 \mathrm{~mol} / \mathrm{L}$. Calculated $\mathrm{Nd}(\mathrm{III})$ distribution ratios accounting for the 1:2 or the 1:3 complex differ by less than $20 \%$ for initial aqueous $\mathrm{Nd}(\mathrm{III})$ concentrations $<0.1 \mathrm{~mol} / \mathrm{L}$. Since such small differences fall within experimental uncertainties this loading experiment does not unambiguously support either the $1: 2$ or the $1: 3$ complex.

\section{Conclusions}

DMDOHEMA has been applied for the development and demonstration of DIAMEX and GANEX processes. Addressing a lack of published data, this paper reports distribution ratios for the extraction of nitric acid, Am(III), Cm(III) and lanthanides(III) from 0.1-7 mol/L nitric acid into $0.5-1 \mathrm{~mol} / \mathrm{L}$ DMDOHEMA dissolved in kerosene. 
Nitric acid extraction was modelled accounting for the adducts, $\left(\mathrm{HNO}_{3}\right) \mathrm{L}_{2}$, $\left(\mathrm{HNO}_{3}\right) \mathrm{L}$ and $\left(\mathrm{HNO}_{3}\right)_{2} \mathrm{~L}$, as observed of other diamides. Using a set of extraction constants, experimental data are calculated within $\pm 10 \%$. Better accuracy is achieved when using conditional extraction constants for the $\left(\mathrm{HNO}_{3}\right) \mathrm{L}$ and $\left(\mathrm{HNO}_{3}\right)_{2} \mathrm{~L}$ adducts.

$\mathrm{Am}(\mathrm{III})$ extraction was modelled accounting for the complexes, $\mathrm{Am}\left(\mathrm{NO}_{3}\right)_{3} \mathrm{~L}_{4}$, $\mathrm{Am}\left(\mathrm{NO}_{3}\right)_{3}\left(\mathrm{HNO}_{3}\right) \mathrm{L}_{3}$ and a third complex: $\mathrm{Am}\left(\mathrm{NO}_{3}\right)_{3}\left(\mathrm{HNO}_{3}\right)_{2} \mathbf{L}_{3}$ (considering spectroscopic results) or $\mathrm{Am}\left(\mathrm{NO}_{3}\right)_{3}\left(\mathrm{HNO}_{3}\right)_{2} \mathbf{L}_{2}$ (considering slope analysis results). Small differences are observed between these models for initial nitric acid concentrations $\geq 4 \mathrm{~mol} / \mathrm{L}$, with the 1:2 complex yielding slightly better agreement between calculations and experiment. While this model does not account for aggregation it allows calculating distribution ratios for the extraction of nitric acid and of actinide(III) and lanthanide ions with reasonable accuracy.

Separation factors between Am(III) and Cm(III) or light lanthanides(III) essentially do not vary with nitric acid concentration. Hence, the proposed equilibrium model is applicable not only for the extraction of Am(III) but also Cm(III) and the "fission lanthanides".

While not intended to resolve the contradictions in organic phase speciation reported in the literature, the proposed equilibrium model may be useful as a basis for process flow-sheet calculations: it covers the full range of nitric acid concentrations expected across the extraction, scrubbing and stripping sections of a multi-stage counter-current process. Furthermore, the study covers a range of DMDOHEMA concentrations, $0.5-1 \mathrm{~mol} / \mathrm{L}$, relevant to process development.

\section{Funding}

Financial support for this research was provided by the European Commission via the projects GENIORS (Horizon 2020 grant agreement № 755171), SACSESS (FP7-Fission-2012-323282) and EUROPART (FI6W-CT-2003-508854).

\section{References}

1. Musikas, C.; Hubert, $\mathrm{H}$., The extraction by $N, N$ '-tetraalkylmalonamides $\mathrm{I}$. The $\mathrm{HClO}_{4}$ and $\mathrm{HNO}_{3}$ extraction. Solvent Extr. Ion Exch. 1987, 5 (1), 151-174.

2. Musikas, C.; Hubert, H., Extraction by $N, N^{\prime}$-tetraalkylmalonamides II. Extraction of metallic ions. Solvent Extr. Ion Exch. 1987, 5 (5), 877-893.

3. Musikas, C., Potentiality of nonorganophosphorus extractant in chemical separations of actinides. Separ. Sci. Technol. 1988, 23 (12-13), 1211-1226.

4. Cuillerdier, C.; Musikas, C.; Hoel, P.; Nigond, L.; Vitart, X., Malonamides as new extractants for nuclear waste solutions. Separ. Sci. Technol. 1991, 26 (9), 1229-1244. 
The Version of Record of this manuscript has been published and is available in SOLVENT EXTRACTION \& ION EXCHANGE 21 July 2020 http://www.tandfonline.com/doi/10.1080/07366299.2020.1794523

5. $\quad$ Cuillerdier, C.; Musikas, C.; Nigond, L., Diamides as actinide extractants for various waste treatments. Separ. Sci. Technol. 1993, 28 (1-3), 155-175.

6. Manchanda, V. K.; Pathak, P. N., Amides and diamides as promising extractants in the back end of the nuclear fuel cycle: an overview. Separ. Purif. Technol. 2004, 35 (2), 85-103.

7. Leoncini, A.; Huskens, J.; Verboom, W., Ligands for f-element extraction used in the nuclear fuel cycle. Chem. Soc. Rev. 2017, 46 (23), 7229-7273.

8. Hill, C., Overview of recent advances in An(III)/Ln(III) separation by solvent extraction. In Ion Exchange and Solvent Extraction, Moyer, B. A., Ed. CRC Press: Boca Raton, London, New York, 2010 ; Vol. 19, pp 119-193.

9. Modolo, G.; Geist, A.; Miguirditchian, M., Minor actinide separations in the reprocessing of spent nuclear fuels: recent advances in Europe. In Reprocessing and Recycling of Spent Nuclear Fuel, Taylor, R., Ed. Woodhead Publishing: Cambridge, UK, 2015.

10. Mastretta, R.; Poirot, R.; Bourgeois, D.; Meyer, D., Palladium isolation and purification from nitrate media: efficient process based on malonamides. Solvent Extr. Ion Exch. 2019, 37 (2), 140-156.

11. Madic, C.; Hudson, M. J. High-level liquid waste partitioning by means of completely incinerable extractants; EUR 18038, European Commission, Luxembourg: 1998.

12. Berthon, L.; Morel, J. M.; Zorz, N.; Nicol, C.; Virelizier, H.; Madic, C., DIAMEX process for minor actinide partitioning: hydrolytic and radiolytic degradations of malonamide extractants. Separ. Sci. Technol. 2001, 36 (5-6), 709-728.

13. Baron, P.; Charbonnel, M. C.; Nicol, C.; Berthon, L., State of advancement of DIAMEX process. In Proc. GLOBAL'97 (Internat. Conf. Future Nuclear Systems), Yokohama (Japan), 5-10 October, 1997.

14. Serrano-Purroy, D.; Baron, P.; Christiansen, B.; Malmbeck, R.; Sorel, C.; Glatz, J. P., Recovery of minor actinides from HLLW using the DIAMEX process. Radiochim. Acta 2005, 93 (6), 351-355.

15. Serrano-Purroy, D.; Baron, P.; Christiansen, B.; Glatz, J.-P.; Madic, C.; Malmbeck, R.; Modolo, G., First demonstration of a centrifugal solvent extraction process for minor actinides from a concentrated spent fuel solution. Separ. Purif. Technol. 2005, 45 (2), 157-162.

16. Geist, A.; Gompper, K., Miniature DIAMEX processes in a hollow fibre module micro-plant: process development and optimisation. Radiochim. Acta 2008, 96 (4-5), 211-218.

17. Sorel, C.; Montuir, M.; Espinoux, D.; Lorrain, B.; Baron, P., Technical feasibility of the DIAMEX process. In Proc. Internat. Solvent Extraction Conf. (ISEC 2008), Moyer, B. A., Ed. Tucson, USA, 15-19 September, 2008.

18. Modolo, G.; Vijgen, H.; Serrano-Purroy, D.; Christiansen, B.; Malmbeck, R.; Sorel, C.; Baron, P., DIAMEX counter-current extraction process for recovery of trivalent actinides from simulated high active concentrate. Separ. Sci. Technol. 2007, 42 (3), 439-452

19. Warin, D., Status of the French research program on partitioning and transmutation. J. Nucl. Sci. Technol. 2007, 44 (3), 410-414.

20. Rostaing, C.; Poinssot, C.; Warin, D.; Baron, P.; Lorrain, B., Development and validation of the EXAm separation process for single Am recycling. Proc. Chem. 2012, 7, 367-373.

21. Miguirditchian, M.; Roussel, H.; Chareyre, L.; Baron, P.; Espinoux, D.; Calor, J.-N.; Viallesoubranne, C.; Lorrain, B.; Masson, M., HA demonstration in the Atalante facility of the GANEX $2^{\text {nd }}$ cycle for the grouped TRU extraction. In Proc. Internat. Conf. GLOBAL 2009 (The Nuclear Fuel Cycle: Sustainable Options \& Industrial Perspectives), Paris, France, 6-11 September, 2009. 
The Version of Record of this manuscript has been published and is available in SOLVENT EXTRACTION \& ION EXCHANGE 21 July 2020 http://www.tandfonline.com/doi/10.1080/07366299.2020.1794523

22. Bell, K.; Carpentier, C.; Carrott, M.; Geist, A.; Gregson, C.; Hérès, X.; Magnusson, D.; Malmbeck, R.; McLachlan, F.; Modolo, G.; Müllich, U.; Sypula, M.; Taylor, R.; Wilden, A., Progress towards the development of a new GANEX process. Proc. Chem. 2012, 7, 392-397.

23. Carrott, M. J.; Gregson, C. R.; Taylor, R. J., Neptunium extraction and stability in the GANEX solvent: 0.2 M TODGA/0.5 M DMDOHEMA/kerosene. Solvent Extr. Ion Exch. 2013, 31 (5), 463-482.

24. Brown, J.; McLachlan, F.; Sarsfield, M.; Taylor, R.; Modolo, G.; Wilden, A., Plutonium loading of prospective grouped actinide extraction (GANEX) solvent systems based on diglycolamide extractants. Solvent Extr. Ion Exch. 2012, 30 (2), 127-141.

25. Carrott, M.; Geist, A.; Hérès, X.; Lange, S.; Malmbeck, R.; Miguirditchian, M.; Modolo, G.; Wilden, A.; Taylor, R., Distribution of plutonium, americium and interfering fission products between nitric acid and a mixed organic phase of TODGA and DMDOHEMA in kerosene, and implications for the design of the "EUROGANEX" process. Hydrometallurgy 2015, 152, 139-148.

26. Carrott, M.; Bell, K.; Brown, J.; Geist, A.; Gregson, C.; Hérès, X.; Maher, C.; Malmbeck, R.; Mason, C.; Modolo, G.; Müllich, U.; Sarsfield, M.; Wilden, A.; Taylor, R., Development of a new flowsheet for coseparating the transuranic actinides: the "EURO-GANEX" process. Solvent Extr. Ion Exch. 2014, 32 (5), 447467.

27. Malmbeck, R.; Magnusson, D.; Bourg, S.; Carrott, M.; Geist, A.; Hérès, X.; Miguirditchian, M.; Modolo, G.; Müllich, U.; Sorel, C.; Taylor, R.; Wilden, A., Homogenous recycling of transuranium elements from irradiated fast reactor fuel by the EURO-GANEX solvent extraction process. Radiochim. Acta 2019, 107 (9-11), 917-929.

28. Carrott, M.; Maher, C.; Mason, C.; Sarsfield, M.; Taylor, R., "TRU-SANEX”: A variation on the EURO-GANEX and i-SANEX processes for heterogeneous recycling of actinides Np-Cm. Separ. Sci. Technol. 2016, 51 (13), 2198-2213.

29. Charbonnel, M. C.; Musikas, C., The extraction by $N, N$ '-tetrabutylglutaramides $\mathrm{I} . \mathrm{HNO}_{3}$ and other inorganic acids extraction. Solvent Extr. Ion Exch. 1988, 6 (3), 461-478.

30. Condamines, N.; Musikas, C., The extraction by $\mathrm{N}, \mathrm{N}$-dialkylamides. $\mathrm{I}_{\text {. }} \mathrm{HNO}_{3}$ and other inorganic acids. Solvent Extr. Ion Exch. 1988, 6 (6), 1007-1034.

31. Nigond, L.; Musikas, C.; Cuillerdier, C., Extraction by $N, N, N^{\prime}, N^{\prime}$-tetraalkyl-2-alkyl propane-1,3diamides. I. $\mathrm{H}_{2} \mathrm{O}, \mathrm{HNO}_{3}$ and $\mathrm{HClO}_{4}$. Solvent Extr. Ion Exch. 1994, 12 (2), 261-296.

32. Tian, Q.; Hughes, M. A., The mechanism of extraction of $\mathrm{HNO}_{3}$ and neodymium with diamides. Hydrometallurgy 1994, 36 (3), 315-330.

33. McNamara, B. K.; Lumetta, G. J.; Rapko, B. M., Extraction of europium(III) ion with tetrahexylmalonamides. Solvent Extr. Ion Exch. 1999, 17 (6), 1403-1421.

34. Madic, C.; Hudson, M. J.; Liljenzin, J.-O.; Glatz, J.-P.; Nannicini, R.; Facchini, A.; Kolarik, Z.; Odoj, R. New Partitioning Techniques for Minor Actinides. Final Report; EUR 19149, European Commission, Luxembourg: 2000.

35. Mowafy, E. A.; Aly, H. F., Extraction behaviours of Nd(III), Eu(III), La(III), Am(III), and U(VI) with some substituted malonamides from nitrate medium. Solvent Extr. Ion Exch. 2002, 20 (2), 177-194.

36. Mowafy, E. A.; Aly, H. F., Extraction behaviors of trivalent lanthanides from nitrate medium by selected substituted malonamides. Solvent Extr. Ion Exch. 2006, 24 (5), 677-692.

37. Nigond, L.; Condamines, N.; Cordier, P. Y.; Livet, J.; Madic, C.; Cuillerdier, C.; Musikas, C.; Hudson, M. J., Recent advances in the treatment of nuclear wastes by the use of diamide and picolinamide extractants. Separ. Sci. Technol. 1995, 30 (7-9), 2075-2099. 
38. Chan, G. Y. S.; Drew, M. G. B.; Hudson, M. J.; Iveson, P. B.; Liljenzin, J.-O.; Skalberg, M.; Spjuth, L.; Madic, C., Solvent extraction of metal ions from nitric acid solution using $N, N^{\prime}$-substituted malonamides. Experimental and crystallographic evidence for two mechanisms of extraction, metal complexation and ion-pair formation. J. Chem. Soc. Dalton Trans. 1997, (4), 649-660.

39. Gannaz, B.; Chiarizia, R.; Antonio, M. R.; Hill, C.; Cote, G., Extraction of lanthanides(III) and Am(III) by mixtures of malonamide and dialkylphosphoric acid. Solvent Extr. Ion Exch. 2007, 25 (3), 313-337.

40. Gannaz, B.; Antonio, M. R.; Chiarizia, R.; Hill, C.; Cote, G., Structural study of trivalent lanthanide and actinide complexes formed upon solvent extraction. Dalton Trans. 2006, (38), 4553-4562.

41. Ellis, R. J.; Meridiano, Y.; Chiarizia, R.; Berthon, L.; Muller, J.; Couston, L.; Antonio, M. R., Periodic behavior of lanthanide coordination within reverse micelles. Chem. Eur. J. 2013, 19 (8), 2663-2675.

42. $\quad$ Ellis, R. J.; Meridiano, Y.; Muller, J.; Berthon, L.; Guilbaud, P.; Zorz, N.; Antonio, M. R.; Demars, T.; Zemb, T., Complexation-induced supramolecular assembly drives metal-ion extraction. Chem. Eur. J. 2014, 20 (40), 12796-12807.

43. Weßling, P.; Trumm, M.; Geist, A.; Panak, P. J., Stoichiometry of An(III)-DMDOHEMA complexes formed during solvent extraction. Dalton Trans. 2018, 47 (32), 10906-10914.

44. Muller, J. M.; Berthon, C.; Couston, L.; Zorz, N.; Simonin, J.-P.; Berthon, L., Extraction of lanthanides(III) by a mixture of a malonamide and a dialkyl phosphoric acid. Solvent Extr. Ion Exch. 2016, 34 (2), 141-160.

45. Bosland, L. Études thermodynamique et cinétique de l'extraction des nitrates de lanthanides par un malonamide ( $N, N$ '-dimethyl-N,N'-dioctyl hexyléthoxy malonamide ou DMDOHEMA); Thèse de l'Ecole Centrale Paris. CEA-R-6099, Commissariat à l'énergie atomique: France, 2006.

46. Gannaz, B. Spéciations moléculaire et supramoléculaire de systèmes d'extraction liquide-liquide à base de malonamide et/ou d'acides dialkylphosporiques pour la séparation An(III)/Ln(III); Thèse de l'Université Paris-XI. CEA-R-6159, Commissariat à l'Énergie Atomique: France, 2006.

47. Antonio, M. R.; Chiarizia, R.; Gannaz, B.; Berthon, L.; Zorz, N.; Hill, C.; Cote, G., Aggregation in solvent extraction systems containing a malonamide, a dialkylphosphoric acid and their mixtures. Separ. Sci. Technol. 2008, 43 (9-10), 2572-2605.

48. Meridiano, Y. Organisation des molécules extractantes de type diamide : lien avec les propriétés extractantes ?; Thèse de l'Université Paris-XI. CEA-R- 6228, Commissariat à l'énergie atomique: France, 2009.

49. Meridiano, Y.; Berthon, L.; Crozes, X.; Sorel, C.; Dannus, P.; Antonio, M. R.; Chiarizia, R.; Zemb, T., Aggregation in organic solutions of malonamides: consequences for water extraction. Solvent Extr. Ion Exch. 2009, 27 (5-6), 607-637.

50. Déjugnat, C.; Berthon, L.; Dubois, V.; Meridiano, Y.; Dourdain, S.; Guillaumont, D.; Pellet-Rostaing, S.; Zemb, T., Liquid-liquid extraction of acids and water by a malonamide: I — anion specific effects on the polar core microstructure of the aggregated malonamide. Solvent Extr. Ion Exch. 2014, 32 (6), 601-619.

51. Dourdain, S.; Déjugnat, C.; Berthon, L.; Dubois, V.; Pellet-Rostaing, S.; Dufrêche, J.-F.; Zemb, T., Liquid-liquid extraction of acids by a malonamide: II - anion specific effects in the aggregate-enhanced extraction isotherms. Solvent Extr. Ion Exch. 2014, 32 (6), 620-636.

52. Geist, A., Extraction of nitric acid into alcohol:kerosene mixtures. Solvent Extr. Ion Exch. 2010, 28 (5), 596-607.

53. Ciavatta, L., The Specific Interaction Theory in evaluating ionic equilibria. Annali Di Chimica 1980, 70 (11-1), 551-567. 
The Version of Record of this manuscript has been published and is available in SOLVENT EXTRACTION \& ION EXCHANGE 21 July 2020 http://www.tandfonline.com/doi/10.1080/07366299.2020.1794523

54. Guillaumont, R.; Fanghänel, T.; Fuger, J.; Grenthe, I.; Neck, V.; Palmer, D. A.; Rand, M. H., Chemical Thermodynamics (OECD-NEA TDB). Elsevier: Amsterdam, 2003; Vol. 5.

55. Davis Jr, W.; De Bruin, H. J., New activity coefficients of 0-100 per cent aqueous nitric acid. J. Inorg. Nucl. Chem. 1964, 26 (6), 1069-1083.

56. Marcus, Y.; Kertes, A. S., Ion Exchange and Solvent Extraction of Metal Complexes. WileyInterscience: London, New York, Sydney, Toronto, 1969.

57. Neck, V.; Altmaier, M.; Fanghänel, T., Ion interaction (SIT) coefficients for the $\mathrm{Th}^{4+}$ ion and trace activity coefficients in $\mathrm{NaClO}_{4}, \mathrm{NaNO}_{3}$ and $\mathrm{NaCl}$ solution determined by solvent extraction with TBP. Radiochim. Acta 2006, 94 (9-11), 501-507.

58. Hummel, W.; Anderegg, G.; Puigdomènech, I.; Rao, L.; Tochiyama, O., Chemical Thermodynamics (OECD-NEA TDB). Elsevier: Amsterdam, 2005; Vol. 9.

59. Alcock, K.; Grimley, S. S.; Healy, T. V.; Kennedy, J.; McKay, H. A. C., The extraction of nitrates by tri- $n$-butyl phosphate (TBP). Part 1.- The system TBP + diluent $+\mathrm{H}_{2} \mathrm{O}+\mathrm{HNO}_{3}$. Transactions of the Faraday Society 1956, 52, 39-47.

60. Horwitz, E. P.; Kalina, D. G.; Kaplan, L.; Mason, G. W.; Diamond, H., Selected alkyl(phenyl)- $N, N$ dialkylcarbamoylmethylphosphine oxides as extractants for Am(III) from nitric acid media. Separ. Sci. Technol. 1982, 17 (10), 1261-1279.

61. Tachimori, S.; Sasaki, Y.; Suzuki, S.-I., Modification of TODGA-n-dodecane solvent with a monoamide for high loading of lanthanides(III) and actinides(III). Solvent Extr. Ion Exch. 2002, 20 (6), 687-699.

62. Nave, S.; Modolo, G.; Madic, C.; Testard, F., Aggregation properties of $N, N, N^{\prime}, N^{\prime}$-tetraoctyl-3oxapentanediamide (TODGA) in n-dodecane. Solvent Extr. Ion Exch. 2004, 22 (4), 527-551.

63. Yaita, T.; Herlinger, A. W.; Thiyagarajan, P.; Jensen, M. P., Influence of extractant aggregation on the extraction of trivalent f-element cations by a tetraalkyldiglycolamide. Solvent Extr. Ion Exch. 2004, 22 (4), 553571.

64. Ansari, S. A.; Pathak, P. N.; Manchanda, V. K.; Husain, M.; Prasad, A. K.; Parmar, V. S., $N, N, N^{\prime}, N^{\prime}-$ tetraoctyl diglycolamide (TODGA): a promising extractant for actinide partitioning from high-level waste (HLW). Solvent Extr. Ion Exch. 2005, 23 (4), 463-479.

65. Campbell, E. L.; Holfeltz, V. E.; Hall, G. B.; Nash, K. L.; Lumetta, G. J.; Levitskaia, T. G., Nitric acid and water extraction by T2EHDGA in n-dodecane. Solvent Extr. Ion Exch. 2017, 35 (7), 586-603.

66. Whittaker, D.; Geist, A.; Modolo, G.; Taylor, R.; Sarsfield, M.; Wilden, A., Applications of diglycolamide based solvent extraction processes in spent nuclear fuel reprocessing, part 1: TODGA. Solvent Extr. Ion Exch. 2018, 36 (3), 223-256.

67. Woodhead, D.; McLachlan, F.; Taylor, R.; Müllich, U.; Geist, A.; Wilden, A.; Modolo, G., Nitric acid extraction into a TODGA solvent modified with 1-octanol. Solvent Extr. Ion Exch. 2019, 37 (2), 173-190.

68. Maryutina, T. A.; Litvina, M. N.; Malikov, D. A.; Spivakov, B. Y.; Myasoedov, B. F.; Lecomte, M.; Hill, C.; Madic, C., Multistage extraction separation of Am(III) and Cm(III) in planet centrifuges. Radiochemistry 2004, 46 (6), 596-602.

69. Peppard, D. F.; Mason, G. W.; Maier, J. L.; Driscoll, W. J., Fractional extraction of the lanthanides as their di-alkyl orthophosphates. J. Inorg. Nucl. Chem. 1957, 4 (5-6), 334-343.

70. Geist, A.; Müllich, U.; Magnusson, D.; Kaden, P.; Modolo, G.; Wilden, A.; Zevaco, T., Actinide(III)/lanthanide(III) separation via selective aqueous complexation of actinides(III) using a hydrophilic 2,6-bis(1,2,4-triazin-3-yl)-pyridine in nitric acid. Solvent Extr. Ion Exch. 2012, 30 (5), 433-444. 
The Version of Record of this manuscript has been published and is available in SOLVENT EXTRACTION \& ION EXCHANGE 21 July 2020 http://www.tandfonline.com/doi/10.1080/07366299.2020.1794523

71. Baron, P.; Lecomte, M.; Boullis, B.; Simon, N.; Warin, D., Separation of the long lived radionuclides: current status and future R\&D programme in France. In Proc. Internat. Conf. GLOBAL 2003 (Atoms for Prosperity: Updating Eisenhower's Global Vision for Nuclear Energy), New Orleans, U.S.A., 16-20 November, 2003; pp 508-511.

72. Patil, A. B.; Shinde, V. S.; Pathak, P. N.; Mohapatra, P. K.; Manchanda, V. K., Modified synthesis scheme for $N, N$ '-dimethyl- $N, N$ '-dioctyl-2(2-hexyloxyethyl) malonamide (DMDOHEMA) and its comparison with proposed solvents for actinide partitioning. Radiochim. Acta 2013, 101 (2), 93-100. 